Perwira Journal of Economics and Business (PJEB)

E-ISSN : 2775-572X

Volume 1 Nomor 1

Februari 2021

\title{
PENGARUH MOTIVASI DAN KESEJAHTERAAN TERHADAP SEMANGAT KERJA DAN IMPLIKASINYA TERHADAP KINERJA
}

\author{
Agustin Riyan Pratiwi ${ }^{1}$, Febi Firgiyani ${ }^{2}$ \\ ${ }^{1,2}$ Universitas Perwira Purbalingga \\ agustinriyan@unperba.ac.id
}

\begin{abstract}
ABSTRAK
Penelitian ini bertujuan untuk mengetahui Pengaruh motivasi dan kesejahteraan terhadap semangat kerja dan implikasinya terhadap kinerja. Penelitian ini menggunakan analisis jalur (path analisis) dan pengujiannya menggunakan uji $\mathrm{F}$ test dan $t$ test. Hasil Penelitian menunjukkan bahwa motivasi termasuk dalam kategori tinggi, kesejahteraan pegawai termasuk dalam kategori sangat tinggi, Semangat kerja pegawai termasuk dalam kategori tinggi dan kinerja pegawai termasuk dalam kategori tinggi. Secara keseluruhan dapat disimpulkan terdapat pengaruh motivasi terhadap semangat kerja, terdapat pengaruh kesejahteraan terhadap semangat kerja, terdapat pengaruh semangat kerja terhadap Kinerja terdapat pengaruh secara simultan motivasi dan kesejahteraan terhadap semangat kerja, terdapat pengaruh secara simultan motivasi dan kesejahteraan terhadap semangat kerja dan implikasinya terhadap kinerja.
\end{abstract}

Kata kunci : motivasi, kesejahteraan, semangat kerja kinerja

This research objectives to knot the effect of motivation and morale and welfare of the implications on performance. This study using path analysis (path analysis) and testing using $F$ test and $t$ test. Research shows that motivation in the high category, well-being of employees included in the category of very high morale of employees included in the high category and performance of employees included in the high category. Overall it can be concluded there is a motivational effect on morale, there is the effect of welfare on morale, there is the influence the morale of the performance there are significant simultaneously motivation and well-being against the spirit of the work, there is the effect of simultaneous motivation and well-being against the spirit of the work and its implications for performance.

Keywords: motivation, welfare, morale performance

PENDAHULUAN

Melihat fenomena yang terjadi bahwa kinerja pemerintahan Kabupaten Purbalingga belum memuaskan. Ukurannya, indeks pelayanan publik dan parameternya kepuasan masyarakat.
Seperti halnya dalam melayani masyarakat dalam membuat KTP, kartu sehat, BPJS, Keterangan menikah, izin pengusaha dan lainnya harus diperbaiki. Faktornya bisa dari sumber daya manusianya, mentalitas aparaturnya dan 
mungkin minimnya keteladanan dari pemimpin -pemimpinnya" (Radar Banyumas, 2015).

Sedangkan reformasi manajemen sektor publik, terkait dengan perlunya digunakan model manajemen Pemerintahan yang baru yang sesuai dengan tuntutan perkembangan jaman, karena perubahan tidaklah sekedar perubahan paradigma namun juga perubahan manajemen. Peningkatan kinerja tentu saja tidak lepas dari faktorfaktor yang mempengaruhinya. Dari berbagai faktor yang mempengaruhi peningkatan kinerja sebuah organisasi, dengan mendasarkan pada asumsi dan karakteristik penelitian di SETDA Kota Purbalingga, maka kami dapat melihat, merasakan dan menangkap adanya gejala menarik untuk dikaji : bagaimana motivasi kerja, dan kesejahteraan terhadap semangat kerja komitmen terhadap organisasi mempengaruhi kinerja pegawai demi terciptanya tujuan organisasi. Pentingnya pengembangan sumber daya manusia dalam organisasi publik (Pemerintah) merupakan hal yang sudah tidak dapat ditawar-tawar lagi, disamping sumber daya lainnya berupa peralatan, mesin dan teknologi, dalam pencapaian tujuannya. Pegawai atau karyawan dalam bekerja sehari-hari pasti akan mengharapkan sebuah motivasi dari organisasi tempat mereka bekerja.

Motivasi yang rendah cenderung akan melemahkan semangat karyawan dalam bekerja. Oleh karena itu pimpinan pada Kantor Sekretariat Daerah Kota Purbalingga harus memperhatikan hal ini, karena motivasi yang diberikan kepada pegawai negeri sipil pada Kantor Sekretariat Daerah Kota Purbalingga masih sangat kurang, maka perlu peningkatan motivasi kepada seluruh pegawai. Motivasi merupakan salah satu komponen penting dalam meraih keberhasilan suatu proses kerja, karena memuat unsur pendorong bagi seseorang untuk melakukan pekerjaan sendiri maupun kelompok.

Ditinjau dari segi organisasi, pegawai yang berkomitmen rendah akan berdampak pada turn over, tingginya absensi, meningkatnya kelambanan kerja. Dengan demikian, tingkat absensi atau tingkat kehadiran pegawai yang rendah secara langsung akan berpengaruh terhadap hasil kerja kurang optimal. Dari rata-rata 25 (dua puluh lima) hari kerja setiap bulannya banyak pegawai yang tidak hadir kerja atau absen dengan alasan izin keperluan keluar dan ijin tanpa keterangan. Hal ini menunjukkan bahwa ada permasalahan yang perlu mendapatkan perhatian oleh manajemen Kantor Sekretariat Kota Purbalingga dalam upaya peningkatan kinerja pegawainya adalah faktor motivasi pegawai.

Dalam hal ini motivasi pegawai pada Kantor Sekretariat Daerah Kota Purbalingga dianggap belum maksimal, terbukti kurangnya para pegawai diberikan kesempatan menempuh pendidikan dan pelatihan sesuai bidang pekerjaannya, adanya pegawai ditempatkan pada bagian yang pekerjaannya bersifat monoton dan kurang bervariasi. Sudah barang tentu pegawai merasa bosan dalam bekerja atau juga penatnya pekerjaan dilakukan oleh pegawai, menjadikan pegawai merasa jenuh. Selain itu dalam promosi jabatan ke jenjang lebih atas, kenyataannya belum berdasarkan pangkat/golongan serta prestasi dari pada pegawai. Dengan demikian apabila harapan dari pegawai dapat terpenuhi maka pegawai dapat termotivasi sehingga dapat meningkatkan kinerja pegawai. Berkenaan dengan masalah kesejahteraan pegawai tersebut, sebenarnya banyak faktor yang mempengaruhi ketidakpuasan pegawai dalam pekerjaannya diantaranya adalah 
sistem imbalan yang tidak adil menurut persepsi pegawai. Karena setiap pegawai akan membandingkan antara rasio hasil dengan input dirinya terhadap rasio hasil dengan input orang lain. Perlakuan yang tidak sama baik dalam reward maupun punishment merupakan sumber kepuasan atau ketidakpuasan pegawai. Disamping itu terbukti adanya pegawai yang merasa gajinya belum bisa mencukupi kebutuhan hidup, kurangnya pemberian insentif/penghargaan misalnya kenaikan pangkat istimewa atas hasil kerja/prestasi kerja yang dicapai oleh pegawai. Satu hal lagi permasalahan yang mempengaruhi kinerja pegawai pada Kantor Sekretariat Daerah Kota Purbalingga menurun adalah pegawai yang kurang memiliki komitmen organisasional. Ini dapat dilihat meningkatnya kelambanan kerja, masih adanya pegawai yang memanfaatkan waktu kerja untuk melakukan hal-hal diluar pekerjaannya, tingginya absensi karyawan, banyak pegawai yang meninggalkan kantor pada jam kerja. Sehubungan dengan hal tersebut Kantor Sekretariat Daerah Kota Purbalingga dalam upaya meningkatkan kinerja pegawainya perlu memperhatikan masalah yang berkaitan dengan motivasi kerja dan kesejahteraan kerja serta semangat kerja komitmen organisasional sehingga dapat lebih memberikan dukungan bagi menajemen dalam suatu pemerintahan diperlukan adanya suatu kajian bersifat penelitian, yaitu tentang "Pengaruh motivasi dan kesejahteraan terhadap semangat kerja dan implikasinya terhadap kinerja aparat"

\section{KAJIAN PUSTAKA}

Motivasi dapat berupa motivasi intrinsik dan ekstrinsik. Motivasi yang bersifat intrinsik adalah manakala sifat pekerjaan itu sendiri yang membuat seorang termotivasi, orang tersebut mendapat kepuasan dengan melakukan pekerjaan tersebut bukan karena rangsangan lain seperti status ataupun uang atau bisa juga dikatakan seorang melakukan hobbynya. Sedangkan motivasi ekstrinsik adalah manakala elemen-elemen diluar pekerjaan yang melekat di pekerjaan tersebut menjadi faktor utama yang membuat seorang termotivasi seperti status ataupun kompensasi

Hal di atas motivasi mampu memberikan dampak yang baik terhadap kinerja aparat. Adapun indikator dari motivasi ini adalah :

Berikut unsur -unsur yang diajdikan indikator dalam memotivasi karyawan menurut Herzberg dalam Robert L. Malthis (2009: 115):

1. Prestasi;

2. Pengakuan;

3. Pekerjaan itu sendiri;

4. Tanggung Jawab;

5. Kemajuan.

Tidak hanya motivasi yang dapat mempengaruhi terhadap kinerja ada pula kesejahteraan yang merupakan Program kesejahteraan yang diberikan oleh perusahaan, lembaga atau organisasi pada pegawainya hendaknya bermanfaat, sehingga dapat mendorong tercapainya tujuan perusahaan yang efektif. Program kesejahteraan karyawan sebaiknya sesuai dengan ketentuan yang telah ditetapkan oleh perusahaan dan tidak melanggar peraturan pemerintah. Adapun indikator dari kesejahteraan karyawan ini adalah :

1. Tunjangan yang menggantikan penghasilan: Tunjangan jabatan, Tunjangan perbaikan penghasilan;

2. Tunjangan yang memberikan rasa aman: Asuransi kesehatan/ASKES, Tunjangan perjalanan dinas;

3. Tunjangan yang dapat dipandang sebagai kesempatan bagi karyawan: Program pelatihan, Fasilitas 
pemberian kredit, Fasilitas imventaris kendaraan jabatan, Tunangan anak.

Menurut Nitisemito (2008), indikator yang menunjukkan kecenderungan umum rendahnya semangat kerja adalah rendahnya produktivitas, tingkat absensi yang tinggi, labour turnover yang tinggi, tingkat kerusakan yang tinggi, kegelisahan di mana-mana, tuntutan yang sering kali terjadi, dan pemogokan. Berdasarkan indikasi yang menunjukkan kecenderungan rendahnya semangat kerja, maka karakteristik semangat kerja karyawan dapat diketahui dari tiga indikator, yaitu budaya organisasi, kompensasi dan motivasi.

Nawawi (2008:207) mengatakan bahwa faktor yang mempengaruhi semangat kerja pegawai adalah minat atau perhatian terhadap pekerjaan, upah/gaji, status sosial berdasarkan jabatan, tujuan mulia dan pengabdian, suasana lingkungan kerja, dan hubungan manusiawi. Sedangkan mengenai semangat kerja membutuhkan perhatian yang teratur, diagnosis dan pengobatan yang layak seperti halnya dengan kesehatan. Semangat kerja agak sukar diukur karena sifatnya abstrak. Semangat kerja merupakan gabungan dari kondisi fisik, sikap, perasaan, dan sentimen pegawai. Untuk mengetahui adanya semangat kerja yang rendah dalam pemerintahan dapat mengetahui faktor penyebabnya dan berusaha untuk mengambil suatu tindakan yang lebih dini.

1. Presensi;

2. Disiplin Kerja;

3. Kerjasama;

4. Tanggung jawab;

5. Produktivitas Kerja.

Miner (Sudarmanto, 2009 : 11-12), mengemukakan 4 (empat) indikator yang dijadikan sebagai tolak ukur dalam menilai kinerja, yaitu :
1. Kualitas, yaitu : tingkat kesalahan, kerusakan,kecermatan;

2. Kuantitas,yaitu jumlah pekerjaan yang dihasilkan;

3. Penggunaan waktu dalam bekerja, yaitu tingkat ketidak hadiran, keterlambatan waktu kerja efektif/jam kerja hilang;

4. Kerja sama dengan orang lain dalam bekerja.

Organisasi pemerintah diharapkan untuk bisa menciptakan suatu motivasi adalah dengan memberikan kesejahteraan yang cukup dan memadai serta dorongan semangat kerja yang berkualitas. Hasil penelitian sebelumnya memberikan contoh fakta bahwa pelaksanaan kesejahteraan berpengaruh terhadap kinerja pegawai ini dilakukan di pegawai salon SPA yang sama membutuh kan kesejahteraan sebagai motivasi. Penelitian berdasarkan hasil uji $\mathrm{F}$, nilai Fhtiung lebih besar dari Ftabel yaitu sebesar 34,3 dapat disimpulkan bahwa tingkat kesejahteraan, kepuasan kerja, dan komitmen organisasi secara simultan berpengaruh signifikan terhadap kinerja karyawan pada Aroma Spa Sanur. Hasil penelitian sesuai dengan hipotesis pertama yang menyatakan bahwa terdapat pengaruh signifikan secara simultan antara tingkat kesejahteraan, kepuasan kerja, dan komitmen organisasi terhadap kinerja karyawan. Hasil ini diamini oleh penelitian yang dilakukan oleh Cemal et al. (2012) dan Marbun (2007:96).

\section{METODE PENELITIAN}

Metode penelitian yang digunakan dalam penelitian ini adalah metode penelitian suvey, yang menurut Gima Sugiama (2008: 38) adalah: "penelitian dengan cara mengajuakan pertanyaan kepada orang - orang atau subjek dan merekam jawaban tersebut untuk kemudian dianalisis secara kritis" 
Adapun populasi dalam penelitian ini adalah pegawai Setda Pemerintah Kota Purbalingga yaitu sebanyak 120 orang. Sampel adalah sebagian nilai yang diambil dari populasi. Pengambilan sampel diambil secara sensus yaitu teknik penentuan sampel bila semua anggota populasi digunakan sebagai sampel. Adapun jumlah sampel dalam penelitian ini sebanyak 120 orang. Data yang diperoleh dari penelitian ini, kemudian dianalisis dengan menggunakan statistik untuk mengetahui pengaruh motivasi dan kesejahteraan, terhadap semangat kerja dan implikasinya terhadap kinerja pegawai Sekertariat Daerah Kota Purbalingga yaitu dengan menggunakan path analysis (analisis jalur). Path analysis (analisa jalur) dalam gambaran structural path analysis di atas dijelaskan bahwa ada hubungan antara X1 (Motivasi Kerja), X2 (Kesejahteraan), dan X3 (Semangat Kerja) terhadap Y (Kinerja). Perhitungan Path Analysis di atas dibantu menggunakan program SPSS

\section{Hasil Penelitian}

\section{Motivasi pada Kantor Sekretariat Daerah Kota Purbalingga}

Motivasi merupakan satu penggerak dari dalam hati seseorang untuk melakukan atau mencapai sesuatu tujuan. Motivasi juga bisa dikatakan sebagai rencana atau keinginan untuk menuju kesuksesan dan menghindari kegagalan hidup. Dengan kata lain motivasi adalah sebuah proses untuk tercapainya suatu tujuan. Seseorang yang mempunyai motivasi berarti ia telah mempunyai kekuatan untuk memperoleh kesuksesan dalam kehidupan. Motivasi dapat berupa motivasi intrinsik dan ekstrinsik. Motivasi yang bersifat intrinsik adalah manakala sifat pekerjaan itu sendiri yang membuat seorang termotivasi, orang tersebut mendapat kepuasan dengan melakukan pekerjaan tersebut bukan karena rangsangan lain seperti status ataupun uang atau bisa juga dikatakan seorang melakukan hobbynya. Sedangkan motivasi ekstrinsik adalah manakala elemen-elemen diluar pekerjaan yang melekat di pekerjaan tersebut menjadi faktor utama yang membuat seorang termotivasi seperti status ataupun kompensasi

Dari perhitungan di atas terhadap tanggapan pegawai atas mengenai motivasi pada Kantor Sekretariat Daerah Kota Purbalingga mendapatkan skor sebesar 2441. hal ini berarti termasuk dalam kategori tinggi. Adapun nilai skor tertinggi dari pengisian kuesioner adalah mengenai motivasi yang sudah diberikan dapat meningkatkan kemajuan dalam bekerja dan yang terkecil mengenai Tanggung jawab atas pekerjaan yang dikerjakan adalah tanggung jawab sendirisendiri. Hal ini berarti bahwa motivasi pegawai di kantor sekretariat daerah Kota Purbalingga sudah menunjukkan karakteristik yang baik yang dibuktikan dengan motivasiyang telah diberikan mampu meningkatkan semangat kerja pegawai.

\section{Kesejahteraan Pegawai Pada kantor Sekretariat Daerah Kota Purbalingga}

Program kesejahteraan yang diberikan oleh suatu institusi, lembaga atau organisasi pada pegawainya hendaknya bermanfaat, sehingga dapat mendorong tercapainya tujuan institusi yang efektif. Program kesejahteraan pegawai sebaiknya sesuai dengan ketentuan yang telah ditetapkan oleh perusahaan dan tidak melanggar peraturan pemerintah. Salah satu contoh yang sudah diberikan adalah kompensasi. Kompensasi pelengkap atau disebut pula fring benefit merupakan salah satu bentuk kompensasi berupa penyediaan paket benefit dan program -program pelayanan karyawan, 
dengan maksud pokok untuk mempertahankan keberadaan karyawan sebagai anggota organisasi dalam jangka panjang. Kalau upah dan gajih merupakan kompensasi langsung (direct compensation) karena langsung berkaitan dengan prestasi kerja, maka fring benefit merupakan kompensasi tidak langsung (indirect compensation) karena tidak langsung berkaitan dengan prestasi kerja

Dari perhitungan terhadap tanggapan pegawai atas mengenai Kesejahteraan Pegawai Pada kantor Sekretariat Daerah Kota Purbalingga mendapatkan skor sebesar 3054. hal ini berarti termasuk dalam kategori sangat tinggi. Adapun nilai skor tertinggi dari pengisian kuesioner variabel kesejahteraan ini adalah mengenai tunjangan yang diberikan sangat membantu atas keuangan keluarga dan skor terkecil yaitu mengenai tunjangan yang diberikan mampu menambah penghasilan dan juga menggantikan penghasilan. Hal ini berarti bahwa kesejahteraan di kantor sekretariat daerah Kota Purbalingga sudah menunjukkan tepat hal ini dikarenakan pegawai menjawab pertanyaan dengan sangat tinggi mengenai kesejahteraan ini.

\section{Semangat Kerja Pada Kantor Sekretariat Daerah Kota Purbalingga}

Semangat kerja dalam melakukan pekerjaan secara lebih giat, sehingga dengan demikian pekerjaan akan dapat diharapkan lebih cepat dan lebih baik. Semangat kerja dapat diartikan juga sebagai suatu iklim atau suasana kerja yang terdapat di dalam suatu organisasi yang menunjukkan rasa kegairahan di dalam melaksanakan pekerjaan dan mendorong mereka untuk bekerja secara lebih baik dan lebih produktif. Unsur penting dari semangat kerja adalah adanya keinginan untuk mencapai tujuan dari sebuah kelompok tertentu. Sebuah contoh yang tepat dari semangat kerja adalah adanya kepahlawanan dalam perang, ketika seseorang menyerahkan nyawanya, maka tubuhnya dapat mempunyai sebuah kesempatan atau dapat mencapai sebuah tujuan. Atau juga dalam pelaksanaannya bahwa semangat kerja diartikan sebagai sikap perseorangan atau sikap kelompok orang-orang terhadap pekerjaan dan lingkungan pekerjaan. Hal ini jelas bahwa setiap pegawai dalam melaksanakan pekerjaannya memerlukan semangat kerja yang tinggi dalam suasana batin yang menyenangkan, bagi terciptanya usaha untuk berpartisipasi dalam segala kegiatan.

Berdasarkan hasil perhitungan terhadap tanggapan pegawai atas mengenai semangat kerja pegawai Pada kantor Sekretariat Daerah Kota Purbalingga mendapatkan skor sebesar 2436. hal ini berarti termasuk dalam kategori tinggi. Adapun nilai skor tertinggi dari pengisian kuesioner variabel semangat kerja ini adalah mengenai kehadiran dalam bekerja sangat meningkatkan semangat dalam bekerja karena dapat menilai terhadap prestasi kerja dan terkecil mengenai selalu tepat waktu dalam mengerjakan aktivitas bekerjanya. Hal ini berarti bahwa semangat kerja di kantor sekretariat daerah Kota Purbalingga sudah menunjukkan tepat hal ini dikarenakan pegawai menjawab pertanyaan dengan tinggi mengenai semangat kerja ini.

\section{Kinerja Pegawai Pada Kantor Sekretariat Daerah Kota Purbalingga}

Kinerja pegawai merupakan hasil kerja yang dicapai oleh seseorang karyawan dalam menjalankan tugas kewajibannya sebagai seorang pegawai/karyawan. Dengan demikian persoalan kinerja karyawan juga 
berhubungan dengan persoalan kemampuan orang untuk mengembangkan dirinya agar mampu berkarya mencapai tujuan yang dikehendaki oleh organisasi. keberhasilan atau kinerja seseorang perlu menetapkan suatu ukuran tertentu untuk menilai apakah organisasi itu memiliki kinerja yang tinggi atau rendah. Hasil pencapaian inilah dari usaha yang telah dilakukan yang dapat diukur dengan indikator-indikator tertentu (kinerja individu dan kinerja organisasi).

Berdasarkan hasil perhitungan $\mathrm{s}$ terhadap tanggapan pegawai atas mengenai kinerja pegawai Pada kantor Sekretariat Daerah Kota Purbalingga mendapatkan skor sebesar 3950. hal ini berarti termasuk dalam kategori tinggi. Adapun nilai skor tertinggi dari pengisian kuesioner variabel kinerja ini adalah Kerja sama tim dapat memudahkan penyelesaian pekerjaan dan terkecil mengenai Efektivitas waktu sangat menentukan dalam penilaian kinerja. Hal ini berarti bahwa kinerja di kantor sekretariat daerah Kota Purbalingga sudah menunjukkan baik hal ini dikarenakan pegawai menjawab pertanyaan dengan tinggi mengenai kinerja ini.

\section{Pembahasan}

1. Pengaruh secara simultan motivasi dan kesejahteraan terhadap semangat kerja dan implikasinya terhadap kinerja

Dari hasil perhitungan SPSS, diperoleh nilai $F_{\text {hitung }}$ sebesar 33.724 dengan kriteria penolakan $\mathrm{H}_{0}$, jika $\mathrm{F}_{\text {hitung }}>$ $\mathrm{F}_{\text {tabel}}$, dengan mengambil taraf signifikan $\alpha$ sebesar $5 \%$, maka dari tabel distribusi F- Snedecor diperoleh $\mathrm{F} \alpha ; \mathrm{k}$; (n-k-1) = 120-3-1 adalah sebesar 2.68 atau cukup melihat sig F yaitu 0,000 yang artinya dengan $\alpha$ lebih kecil dari $5 \%$ masih menunjukkan signifikan.

Dikarenakan 33.724 lebih besar dari 2.68 dengan sig F sebesar 0,000, maka Ho ditolak atau dengan kata lain terdapat pengaruh antara motivasi dan kesejahteraan terhadap semangat kerja yang berimplikasi terhadap kinerja pengawai dengan tingkat pengaruh sebesar $41.3 \%$.

Maka dapat disimpulkan bahwa ketiga variabel tersebut motivasi dan kesejahteraan mempunyai pengaruh yang signifikan terhadap semangat kerja yang berimplikasi secara signifikan terhadap kinerja.

Secara lengkap pengaruh antara variabel $\mathrm{X}_{1}$, variabel $\mathrm{X}_{2}$ terhadap $\mathrm{Y}$ berimplikasi terhadap $\mathrm{Z}$ dapat dilihat sebagai berikut:

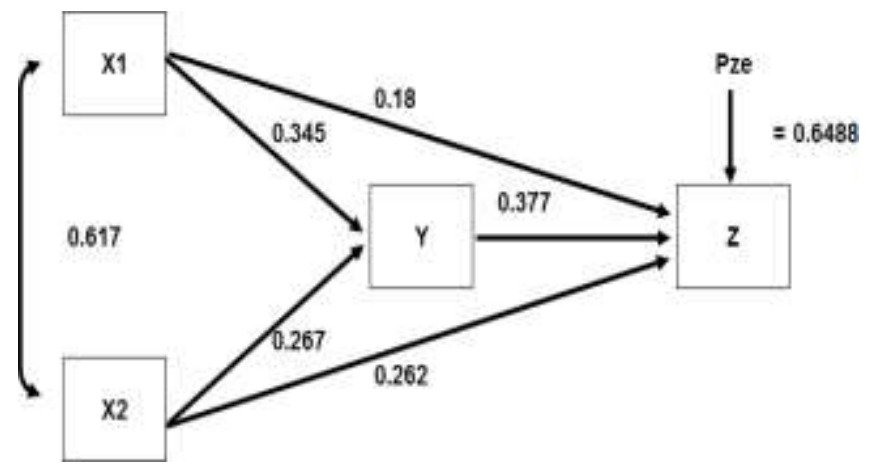

Gambar 1

Struktur 1 nilai Koefisien Jalur Antara

Variabel $X_{1}, X_{2}$ terhadap $Y$ yang berimplikasi terhadap $\mathrm{Z}$

Dari Gambar 1 di atas dapat dilihat pengaruh langsung dan tidak langsung antara variabel yang menunjukkan bahwa secara keseluruhan variabel motivasi $\left(\mathrm{X}_{1}\right)$ kesejahteraan $\left(\mathrm{X}_{2}\right)$, semangat kerja $(\mathrm{Y})$ bersama-sama terhadap kinerja $(\mathrm{Z})$ yaitu sebesar 0.3512 atau $35.12 \%$. Adapun pengaruh lain yang tidak penulis teliti yaitu sebesar 0.6488 atau $64.88 \%$.

\section{Pengaruh secara simultan motivasi dan kesejahteraan terhadap semangat kerja}

Dari hasil perhitungan SPSS, diperoleh nilai $F_{\text {hitung }}$ sebesar 25.523 dengan kriteria penolakan $\mathrm{H}_{\mathrm{o}}$, jika $\mathrm{F}_{\text {hitung }}>$ 
$\mathrm{F}_{\text {tabel, }}$ dengan mengambil taraf signifikan $\alpha$ sebesar $5 \%$, maka dari tabel distribusi F- Snedecor diperoleh F $\alpha ; \mathrm{k} ;(\mathrm{n}-\mathrm{k}-1)=3$ 119-1 adalah sebesar 2.68 atau cukup melihat sig F yaitu 0,000 yang artinya dengan $\alpha$ lebih kecil dari $5 \%$ masih menunjukkan signifikan.

Dikarenakan 25.523 lebih besar dari 2.68 dengan sig $\mathrm{F}$ sebesar 0,000, maka Ho ditolak atau dengan kata lain secara simultan bahwa motivasi $\left(\mathrm{X}_{1}\right)$ dan kesejahteraan $\left(\mathrm{X}_{2}\right)$ berpengaruh terhadap kinerja (Y) sebesar koefisien determinasi 0.304 atau $30.4 \%$.

Maka dapat disimpulkan bahwa kedua variabel tersebut (motivasi dan kesejahteraan) mempunyai pengaruh yang signifikan terhadap semangat kerja. Semakin meningkat motivasi dan kesejahteraan maka semakin meningkat pula kinerja pada kantor dinas sekretariat daerah kota Purbalingga.

Secara lengkap pengaruh antara variabel $\mathrm{X}_{1}$, variabel $\mathrm{X}_{2}$ terhadap $\mathrm{Y}$ dapat dilihat sebagai berikut:

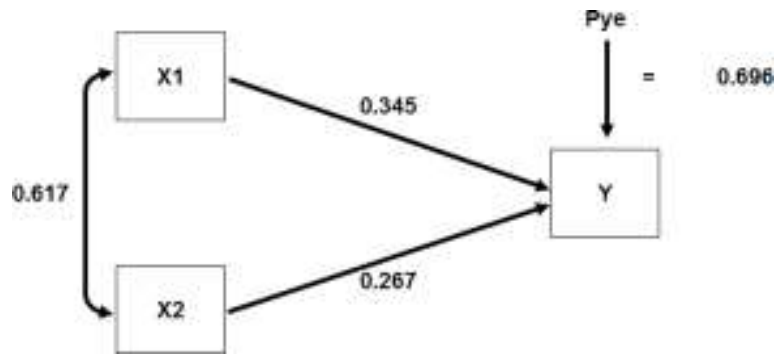

Gambar 2

Sub Struktur 2 Nilai Koefisien Jalur Antara Variabel $X_{1}, X_{2}$ terhadap $Y$

Dari Gambar 2 di atas dapat dilihat pengaruh langsung dan tidak langsung antara variabel, yang menunjukkan bahwa secara keseluruhan variabel motivasi $\left(\mathrm{X}_{1}\right)$ dan kesejahteraan $\left(\mathrm{X}_{2}\right)$ mempunyai pengaruh terhadap semangat kerja sebesar 0.617 dan pengaruh secara simultan antara motivasi dan kesejahteraan terhadap semangat kerja sebesar 0.304. Adapun pengaruh lain yang tidak penulis teliti yaitu sebesar 0.696.

\section{Pengaruh motivasi terhadap semangat kerja pada Kantor Sekretariat Daerah Kota Purbalingga}

Berdasarkan pengolahan data dengan menggunakan SPSS, besar pengaruh motivasi $\left(\mathrm{X}_{1}\right)$ terhadap kinerja (Y) diperlihatkan oleh koefisien beta $(\beta)$ (standardized coefficients) setelah dipengaruhi $\mathrm{X}_{2}$ (motivasi) sebesar 0,345, sedangkan pengaruh langsung sebesar 0,1190 .

Untuk pengujian secara parsial antara motivasi $\left(\mathrm{X}_{1}\right)$ terhadap semangat kerja (Y) dapat dilihat dari perhitungan SPSS untuk analisis jalur. Dengan kriteria penolakan Ho, jika thitung $>t_{\text {tabel, }}$ maka dengan koefisien beta $(\beta)=0,345$,

diperoleh $t_{\text {hitung }}$ sebesar 3.521 dengan mengambil taraf signifikansi sebesar $5 \%$ dan tingkat signifikansinya sebesar 0.001, maka tolak Ho atau dengan kata lain motivasi secara parsial berpengaruh signifikan terhadap semangat kerja.

Hal ini sesuai ha 0.83426 yang lain yang telah dilakukan oleh Muhammad Aris (2014) dengan judul pengaruh motivasi terhadap semangat kerja karyawan PT. Pelni Cabang Samarinda hasil penelitian menunjukkan bahwa bahwa berdasarkan hasil perhitungan yang dibuat, untuk pengujian hipótesis dengan menggunakan "uji t" didapt ttest sebesar 5,849 yang berarti bahwa ttest lebih besar dari ttabel yaitu $5,849>1,686$ dengan nilai kritis $\mathrm{n}-2=$ 48 dengan taraf signifikasi 0,05 artinya menolak Ho dan menerima Ha. Dengan demikian terdapat pengaruh yang signifikan dari variabel motivasi terhadap variabel semangat kerja karyawan pada PT.Pelni Cabang Samarinda, hal ini berarti bahwa hipótesis yang diajukan dan 
dirumuskan didalam penelitian ini dapat diterima dan dibuktikan kebenarannya.

\section{Pengaruh kesejahteraan terhadap semangat kerja pada Kantor Sekretariat Daerah Kota Purbalingga}

Berdasarkan pengolahan data dengan menggunakan SPSS, besar pengaruh kesejahteraan $\left(\mathrm{X}_{2}\right)$ terhadap kinerja (Y) diperlihatkan oleh koefisien beta $(\beta)$ (standardized coefficients)

setelah dipengaruhi $\mathrm{X}_{2}$ (kesejahteraan) pengaruh langsung 0,267 .

Untuk pengujian secara parsial antara kesejahteraan $\left(\mathrm{X}_{2}\right)$ terhadap semangat kerja (Y) dapat dilihat dari perhitungan SPSS untuk analisis jalur. Dengan kriteria penolakan Ho, jika thitung > $\mathrm{t}_{\text {tabel}}$, maka dengan koefisien beta $(\beta)=$ 0,267 , diperoleh thitung sebesar 2.719 dan tingkat signifikansinya sebesar 0.004 dengan mengambil taraf signifikansi sebesar $5 \%$ maka nilai tabel 1,98. Sehingga $t_{\text {hitung }}>\mathrm{t}_{\text {tabel }}$, maka tolak Ho atau dengan kata lain kesejahteraan secara parsial berpengaruh signifikan terhadap semangat kerja.

Hal ini sesuai hasil penelitian yang lain yang telah dilakukan oleh Siska Malisa Nasution (2009) dengan judul Pengaruh Kesejahteraan Karyawan Terhadap Semangat Kerja Karyawan Pada PT. Pangansari Utama Medan, hasil penelitian menunjukkan bahwa hasil penelitian diperoleh, bahwa program kesejahteraan karyawan berpengaruh terhadap semangat kerja karyawan PT. Pangansari Utama Medan. Hal ini berarti bahwa program kesejahteraan karyawan dapat meningkatkan semangat kerja PT. Pangansari Utama Medan. Program kesejahteraan karyawan yaitu kesejahteraan langsung dan kesejahteraan tidak langsung memberikan pengaruh signifikan terhadap semangat kerja karyawan. Berdasarkan nilai koefisien regresi diketahui bahwa semua variabel program kesejahteraan karyawan berpengaruh positif, yang berarti semua variabel program kesejahteraan karyawan berpengaruh dalam meningkatkan semangat kerja karyawan PT. Pangansari Utama Medan. Program kesejahteraan karyawan yang paling dominan mempengaruhi semangat kerja karyawan di PT. Pangansari Utama Medan adalah fasilitas kesejahteraan tidak langsung.

\section{Simpulan}

Berdasarkan hasil analisis dan pembahasan yang diselaraskan dengan permasalahan yang diteliti, maka dapat disimpulkan sebagai berikut :

1. Motivasi, kesejahteraan dan semangat kerja pegawai termasuk dalam kategori tinggi demikian pula kinerja pegawai pada kantor Sekretariat Daerah Kota Purbalingga termasuk dalam kategori tinggi.

2. Terdapat pengaruh secara simultan motivasi dan kesejahteraan terhadap semangat kerja dan implikasinya terhadap kinerja.

3. Terdapat pengaruh motivasi terhadap semangat kerja pada Kantor Sekretariat Daerah Kota Purbalingga.

4. Terdapat pengaruh kesejahteraan terhadap semangat kerja pada Kantor Sekretariat Daerah Kota Purbalingga.

5. Terdapat pengaruh semangat kerja terhadap Kinerja pada Kantor Sekretariat Daerah Kota Purbalingga.

6. Terdapat pengaruh secara simultan motivasi dan kesejahteraan terhadap semangat kerja

\section{DAFTAR PUSTAKA}

A.A. Anwar Prabu Mangkunegara. 2009, Manajemen sumber daya manusia perusahaan, Bandung : Remaja Rosdakarya 
Agus Ahyari, Drs. 2004, Manajemen Produksi, edisi ke empat Jilid ke dua, Penerbit : BPFE, Yogyakarta.

Alex S. Nitisemito. 2008. Manajemen Personalia. Edisi Ke-10. Jakarta : Ghalia Indonesia.

Amstrong, Michael. 2004. Performance Management. Yogyakarta: Tugu. Publisher. Anaroga,

Arep, Ishak dan Hendri Tanjung. 2008. Manajemen Sumber Daya Manusia. Jakarta: Universitas Trisakti.

Bangun, Wilson, 2012, Manajemen Sumber Daya Manusia, Erlangga, Bandung.

C. Certo Samuel and S. Trevis Certo Tahun 2006. Modern Manajemen $10 \mathrm{e}$.

Certo, Samuel C. and Certo, S.Trevis. 2012. Modern Management: Concepts And Skills. New Jersey : Pearson Education, Inc.

Davis, Gordon B. 1993. Kerangka Dasar Sistem Informasi Manajemen. Terjemahan, Seri. Manajemen 90A. Jakarta: PT. Pustaka Binaman Djamaludin. 2008. "Validitas dan Reliabilitas Instrumen Penelitian".

Gomes Faustino Cordoso, "Manajemen Sumber Daya Manusia", Edisi II, Yogyakarta: Andi Ofset.

Hadari Nawawi. 2008. Manajemen Sumber Daya Untuk Bisnis Kompetitif. Cetakan Pertama. Yogyakarta: Gajah Mada University Press Yogyakarta.

Hasibuan Malayu S.P., 2010, Organisasi dan Motivasi, Dasar Peningkatan Produktivitas, Jakarta: Bumi Aksara. 2007. Organisasi

dan Motivasi Dasar Peningkatan Produktivitas. Jakarta: Bumi Aksara.

Henry Simamora. 2004. Manajemen Sumber Daya Manusia. Edisi 3. Yogyakarta: STIE YKPN.
Husein Umar. 2002. Metode Riset Bisnis. Edisi Pertama. Jakarta: PT. Gramedia Pustaka Utama.

Irawan, Prasetya, dkk. 2000. Manajemen Sumber Daya Manusia. Jakarta: Sekolah. Tinggi Ilmu Administrasi. Jimoh, A.M., 2008, "Emotional Labour, Conscientiousness and Job Tenure as Predictors of Job Performance Among University Administrative Workers in Southwestern Nigerian",International Journal of African \& African American Studies, Vol.VII, No.2

M.Manullang, $2005 . \quad$ Dasar_Dasar Manajemen . Gadjah Mada University Press.

Masíud, Fuad. 2004. Survai Diagnosis Organisasional Konsep \& Aplikasi.Badan Penerbit Universitas Diponegoro. Semarang. Mudrasah Sinungan. 2003. "Evaluasi Atas Kegiatan Gerakan Produktifitas Nasional” Jakarta: Yayasan Produktifitas Nasional.

Mulyadi, (2001), Balanced Scorecard : Alat Manajemen Kontemporer untuk Pelipatgandaan Kinerja Keuangan Perusahaan, Salemba Empat, Jakarta.

Robbins, Stephen P, 2006, "Perilaku Organisasi, Edisi kesepuluh, PT Indeks. Jakarta.

Robert L. Mathis, 2006. Human Resource Management (edisi 10). Salemba empat: Jakarta.

Robert L. Mathis, John H Jackson, 2004 , Human Resources Management, Edisis kesepuluh, Jakarta: Salemba Empat.

Sadamaryanti, 2011, Manajemen Sumber Daya Manusisa (Reformasi Birokrasi).

2011. Sumber Daya Manusia dan Produktivitas Kerja. Bandung: Mandar Maju. 
Simamora, Henry, 2003, Manajemen Sumber Daya Manusia, Yogyakarta; STIE

Sirait Justine.,Dra.,M.B.A.-T., 2006. Memahami Aspek -Aspek Pengelolaan Sumber Daya Manusia dalam Organisasi. Jakarta : Grasindo

Sirait, T. Justine, 2007, Aspek-aspek pengelolaan sumber daya manusia dalam organisasi, cetakan ke-dua, Jakarta: Grasindo.

Sitepu, 1994, Analisis Jalur (Path Analysis),Unit Pelayanan Statitika Jurusan Statistika, Bandung : FMIPA UNPAD

Soelaiman, Sukmalana. 2007.

Manajemen Kinerja : Langkah Efektif untuk Membangun, Mengendalikan dan Evaluasi Kerja. Jakarta : PT. Intermedia Personalia Utama.

Sondang P. Siagian, 2003, Manajemen Sumber Daya Mnusia, Jakarta: PT. Rineka Cipta.

Sudjana, 2000, Metode Statistik, Tarsito: Bandung

Sugiyono. 2007. Metode Penelitian Kuantitatif Kualitatif dan R\&D. Bandung: Alfabeta.

Sulaeman, M. (2018). Pengaruh Motivasi Dan Kepuasan Kerja Terhadap Disiplin Kerja Dan Dampaknya Terhadap Kinerja Pegawai Dinas Pertanian Dan Ketahanan Pangan Kota Banjarkepuasan Kerja Terhadap Disiplin Kerja Dan Dampaknya Terhadap Kinerja Pegawai Dinas Pertanian Dan Ketahanan, 1(1), 1-7. https://osf.io/preprints/inarxiv/8wb3 a/

Veithzal Rivai. 2004. Manajemen Sumber Daya Manusia Untuk Perusahaan : Dari Teori Ke Praktik. PT. Raja Grafindo Persada,
Wibowo. 2010. Manajemen Kinerja.

Jakarta : Rajawali press

Wirawan, 2009. Evaluasi Kinerja Sumber Daya Manusia. Jakarta: Salemba.

Wursanto, Ignasius, 2009, Dasar - dasar Ilmu Organisasi, Edisi dua, Yogyakarta: Andi.

Yunus, Hadi Sabari. 2005. Manajemen Kota Yogyakarta. Pustaka Pelajar. 